\title{
Genetic Engineering of Energy Crops to Reduce Recalcitrance and Enhance Biomass Digestibility
}

\author{
Monika Yadav ${ }^{1,+}$, Kunwar Paritosh ${ }^{1,+}$, Aakash Chawade ${ }^{2}$ (D), Nidhi Pareek ${ }^{3}$ and \\ Vivekanand Vivekanand ${ }^{1, *}$ \\ 1 Centre for Energy and Environment, Malaviya National Institute of Technology, Jaipur, \\ Rajasthan 302017, India; 2016ren9012@mnit.ac.in (M.Y.); 2017ren9030@mnit.ac.in (K.P.) \\ 2 Department of Plant Breeding, Swedish University of Agricultural Sciences, P.O. Box 101, \\ 23053 Alnarp, Sweden; aakash.chawade@slu.se \\ 3 Department of Microbiology, School of Life Sciences, Central University of Rajasthan Bandarsindri, \\ Kishangarh, Ajmer, Rajasthan 305801, India; nidhipareek@curaj.ac.in \\ * Correspondence: vivekanand.cee@mnit.ac.in; Tel.: +91-141-271-3573 \\ $\dagger$ These authors contributed equally to this work.
}

Received: 24 April 2018; Accepted: 31 May 2018; Published: 2 June 2018

\begin{abstract}
Bioenergy, biofuels, and a range of valuable chemicals may be extracted from the abundantly available lignocellulosic biomass. To reduce the recalcitrance imposed by the complex cell wall structure, genetic engineering has been proposed over the years as a suitable solution to modify the genes, thereby, controlling the overall phenotypic expression. The present review provides a brief description of the plant cell wall structure and its compositional array i.e., lignin, cellulose, hemicellulose, wall proteins, and pectin, along with their effect on biomass digestibility. Also, this review discusses the potential to increase biomass by gene modification. Furthermore, the review highlights the potential genes associated with the regulation of cell wall structure, which can be targeted for achieving energy crops with desired phenotypes. These genetic approaches provide a robust and assured method to bring about the desired modifications in cell wall structure, composition, and characteristics. Ultimately, these genetic modifications pave the way for achieving enhanced biomass yield and enzymatic digestibility of energy crops, which is crucial for maximizing the outcomes of energy crop breeding and biorefinery applications.
\end{abstract}

Keywords: genetic engineering; biomass; biofuel; digestibility; enzymatic saccharification

\section{Introduction}

Biomass has the potential to provide a renewable form of energy by going through engineered processes, such as anaerobic digestion, fermentation, and gasification [1]. A group of researchers contemplated that, to reduce the overall $\mathrm{CO}_{2}$ to half, renewable energy from biological sources must be squared two times by 2050. Lignocellulosic biomass is a plentiful resource for bioenergy, with an estimated productivity of $1.5 \times 10^{10}$ tons per year and a conversion efficiency of about 0.6 [2]. However, the robust nature of lignocellulosic biomass makes the bioconversion process quite expensive due to the necessity of carrying out pretreatment. The structure of cell wall polymers, and its inability to be converted easily, makes room for genetic modifications [3]. The modifications caused by genetic manipulations also transferred to the upcoming generations, unlike pretreatment methods, which need to be carried out each time. Therefore, genetic modifications seem to be a one-time investment for bringing about the desired changes in bioenergy crops for the long term [4].

Cellulose, hemicelluloses, lignin, and pectins are the key constituents of a plant cell wall complex (Figure 1). The plant cell wall consists of various complicated polymer structures and 
has multidimensional functions. In this regard, genetic amendment of the plant cell wall complex is sometimes related to imperfections in the growth, health, and overall change of the plant cell wall lifespan, considerably affecting the agronomic characters of crops [5]. So, to increase biomass yield by genetic modification, a plant's basic functional cell wall structure for its growth should be taken care, in parallel [3]. Biomass yield can be estimated in terms of the growth of the plant and its parts i.e., height of plant, leaflet size, shoot length, etc. [6-8]. The changes in height or size of the leaflet or shoot are measured by comparing the growth with wild plants without genetic modifications [6-8].

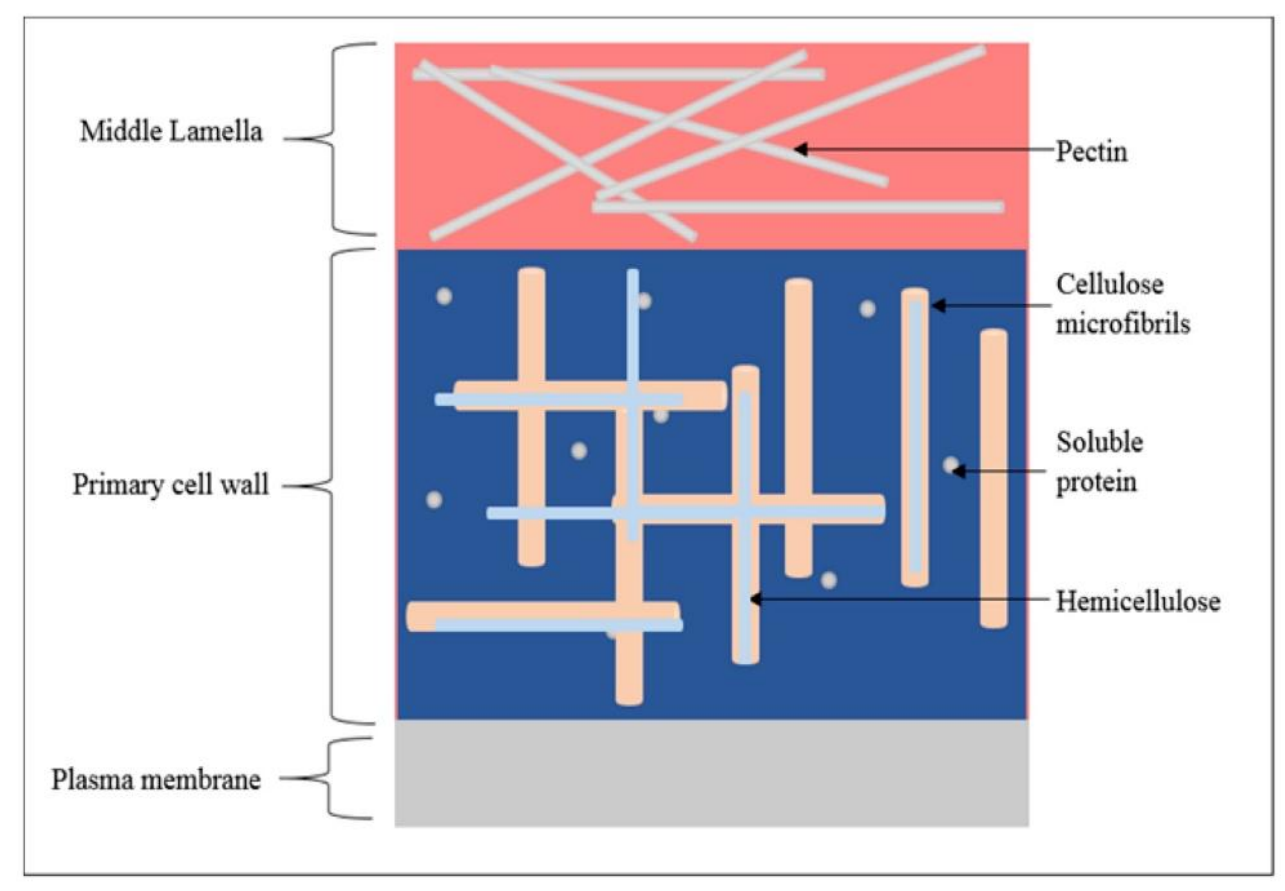

Figure 1. Basic plant cell wall structure.

\section{Biomass Bioconversion and the Plant Cell Wall Complex}

The plant cell complex varies throughout the plant kingdom and, hence, it remains demanding to select polymers on an individual level that influence the enzymatic debasement of feedstock. Cellulose, hemicelluloses, and lignin are the main polymer structures for the identification and characterization of biomass and its bioconversion. In the plant cell wall, cellulose is a high density polymer consisting of $\beta-1,4$-glucan chains (Figure 2). Cellulose shows a semi-crystalline and fibrous structure because of hydrogen bonding (inter and intramolecular) between $\beta-1,4$-glucan forming chains [9]. In the innate state, cellulose molecules are held together by intermolecular hydrogen bonds, but the strong tendency of cellulose to form intramolecular and intermolecular hydrogen bonds increases the rigidity of cellulose. This also makes cellulose highly insoluble and highly resistant to most organic solvents. Cellulose consists of $(1,4)$-D-glucopyranose units, which are attached by $\beta-1,4$ linkages, with an average molecular weight of around 100,000 [9]. Interaction of cellulose with other polymers present in the plant cell wall depends on this fibrous and mechanically strong nature of cellulose crystallinity [10]. For determining crystallinity in agricultural biomass and energy crops experimentally, $\mathrm{X}$-ray diffraction $(\mathrm{XRD})$ is, in general, employed and results are expressed as the crystallinity index (CrI). This factor, $\mathrm{CrI}$, has been reported for affecting the lodging resistance of rice in a negative manner, a trait which determines the yield of crops [5]. 


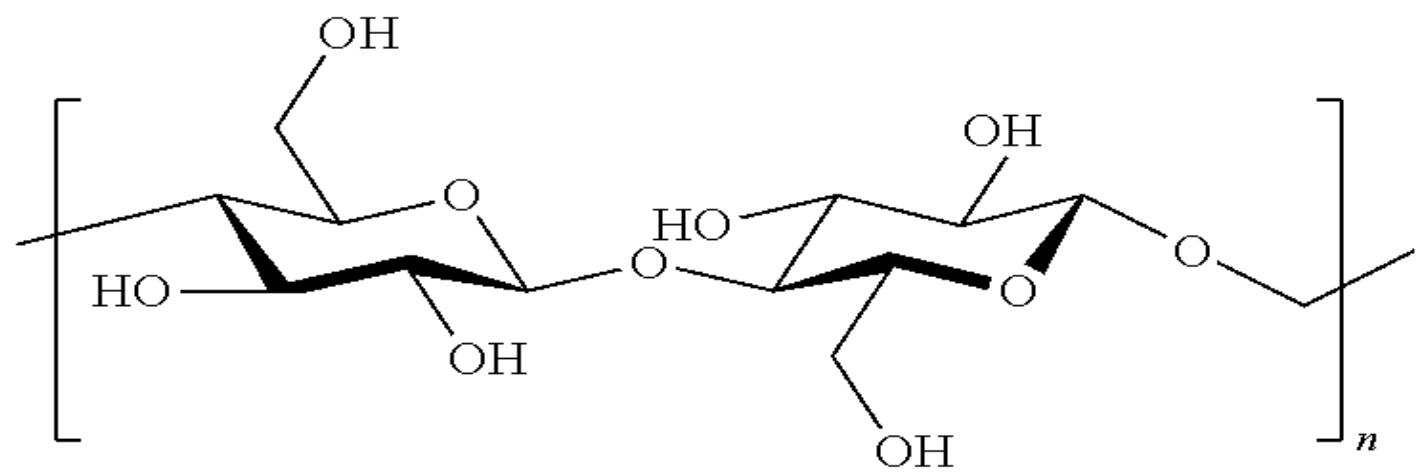

Figure 2. Cellulose structure.

On the other hand, hemicellulose has a dissimilar composition based on plant species. The hemicellulose backbone can be a homopolymer or heteropolymer, and consists of five carbon and six carbon sugars i.e., Xylose in hardwoods and mannose in softwood, with side chains of acetyl, gluconoryl, or arabinofuranosyl units (Figure 3) [11]. Xylans, mannans, and glucans can form backbones, with xylans and mannans being the most common [1]. Galactans, arabinan, and arabinanogalactans are the main sugar monomers in the hemicellulose, but these monomers do not share an equatorial $\beta-1,4$ linked backbone structure. Glucuronoxylan is the prevalent component in hardwood.

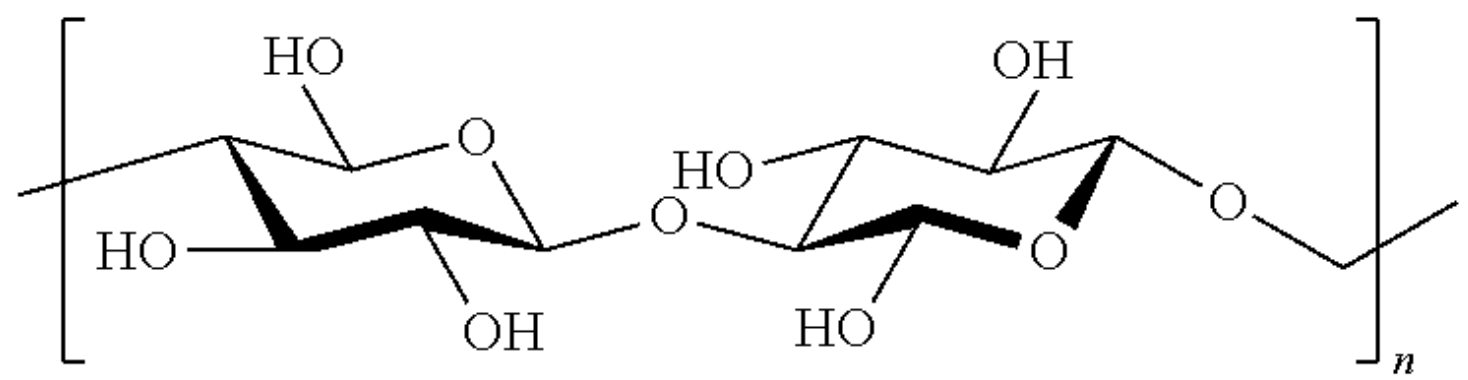

Figure 3. Hemicellulose polymer.

Hemicellulose connects cellulose and lignin with cross linkages formed by covalent and hydrogen bonds. These linkages strengthen the plant cell wall and have a major role in the recalcitrance behavior of these polymers [1]. Apart from cellulose and hemicellulose, lignin is also an important part of the plant cell wall, having complex amorphous polymers of coniferyl sinapyl and coumaryl alcohol. So, as these three components of lignocellulosic biomass are cross linked, they form a sturdy 3-D matrix, which acts as a barrier for enzymatic activity during anaerobic digestion of biomass for biogas production [1]. Lignin acquires around $10-25 \%$ of the lignocellulosic biomass by molecular weight (Table 1). It works as a glue by filling the gap between cellulose and hemicellulose. It contains a large polymer of phenyl- propane, methoxy group, and non-carbohydrate polyphenolic constituents [9]. These constituents bind the cell wall components and phenyl propane works as a main block of lignin. Phenyl-propanes are denoted as 0, I, and II methoxy groups, which are attached to rings and give the special structure of I, II, and III [11]. Structure I exists in plants (grasses), structure II exists in wood (conifers), and structure III is found in deciduous wood. Coniferyl alcohol, sinapyl alcohol, and p-coumaryl alcohol are three monomers of lignin, as shown in Figure 4. 
Table 1. Composition of lignocellulosic biomass [12].

\begin{tabular}{cccc}
\hline Lignocellulosic Biomass & Cellulose (\%) & Hemicellulose (\%) & Lignin (\%) \\
\hline Rice straw & $15-29$ & $9-17$ & $12-18$ \\
Wheat straw & $34-39$ & $21-34$ & $22-25$ \\
Corn stover & $21-37$ & $22-31$ & $14-20$ \\
Switch grass & $31-38$ & $26-34$ & $18-22$ \\
Reed & $34-36$ & 26 & 21 \\
Sugarcane bagasse & $42-45$ & $25-28$ & 20 \\
Miscanthus & $20-40$ & $23-35$ & $19-31$ \\
Rapeseed & $20-35$ & $16-20$ & $15-24$ \\
\hline
\end{tabular}
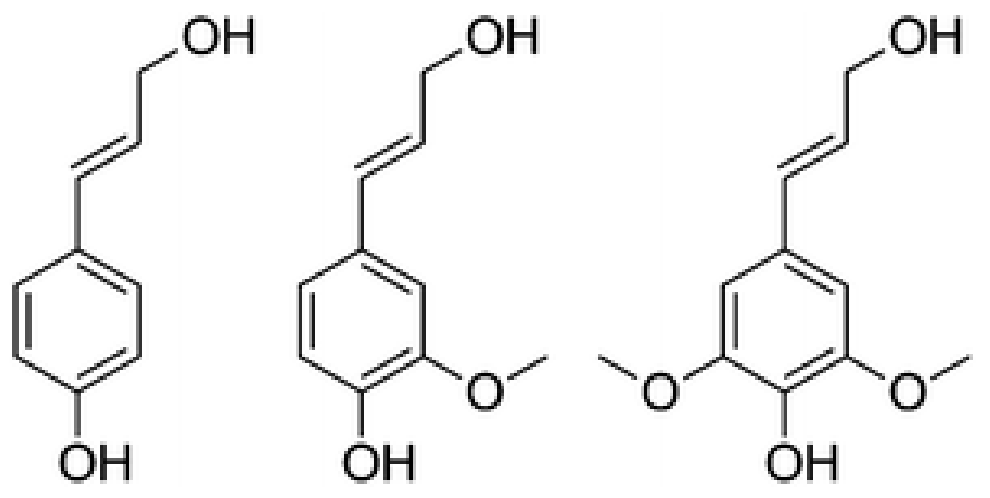

Figure 4. Lignin polymer unit (coumaryl, Coniferyl, and sinapyl alcohol).

Both cellulose and hemicelluloses are biodegradable in an independent form, but in the lignocellulosic substrate they are encrusted by lignin. The crosslinks present between cellulose, hemicelluloses, and lignin polymer forms a physical barrier that makes them inaccessible for enzymatic hydrolysis during anaerobic digestion. Furthermore, the ratio of coniferyl to syringyl monomers in lignin is also a crucial factor to determine the degree of biomass recalcitrance [4]. Identification of key genes involved in lignin biosynthesis could be one of the best strategies towards genetic modification of lignins and esterified phenolic acids in biomass [4].

\section{Genetic Modification in the Plant Cell Wall}

To obtain a high biomass yield, the primary approach adopted by genetic engineers is to improve the polymer synthesis in the cell wall, specifically, targeting cellulose. However, the challenge is to maintain the inherent characteristics of the plant cell wall, which is primarily inclined towards providing mechanical strength and protection to plants rather than providing a biomass yield. Excess compromising with the polymers accounting for these protective features will create interference with optimal plant growth. Therefore, identification of appropriate genes for genetic transformation and mutagenesis is a vital step, along with employing effective promoters [13-16] A plethora of genes, in the count of thousands, are reported to participate in the process of cell wall polymer synthesis, modification, and degradation [17]. Several mutant plants showed improved growth yield and biomass degradation after genetic modifications when compared to the wild type (Figures 5 and 6). The genetic engineering approaches based on these genes have been summarized in the following section. 

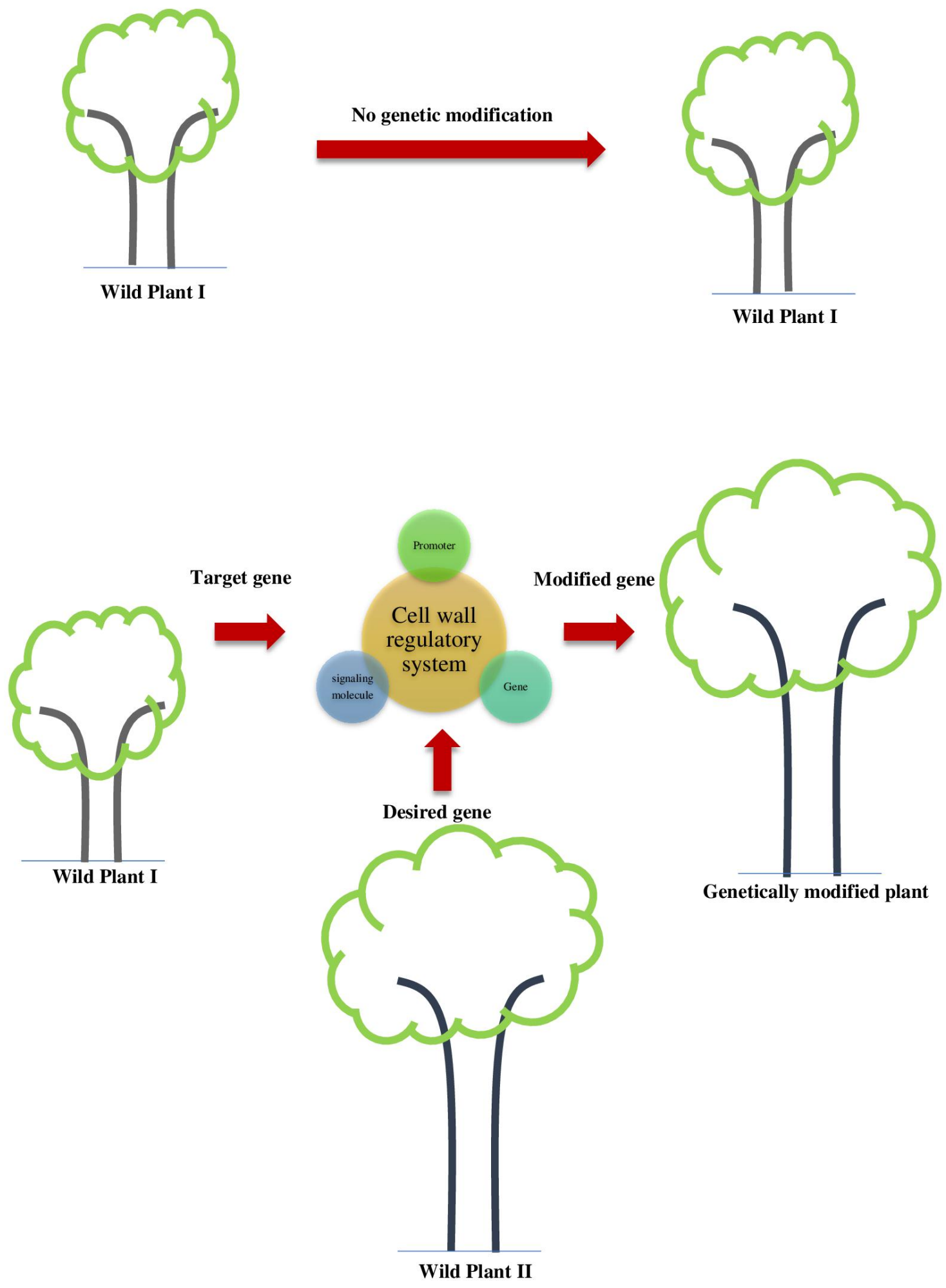

Figure 5. Improved biomass yield after genetic modification. 


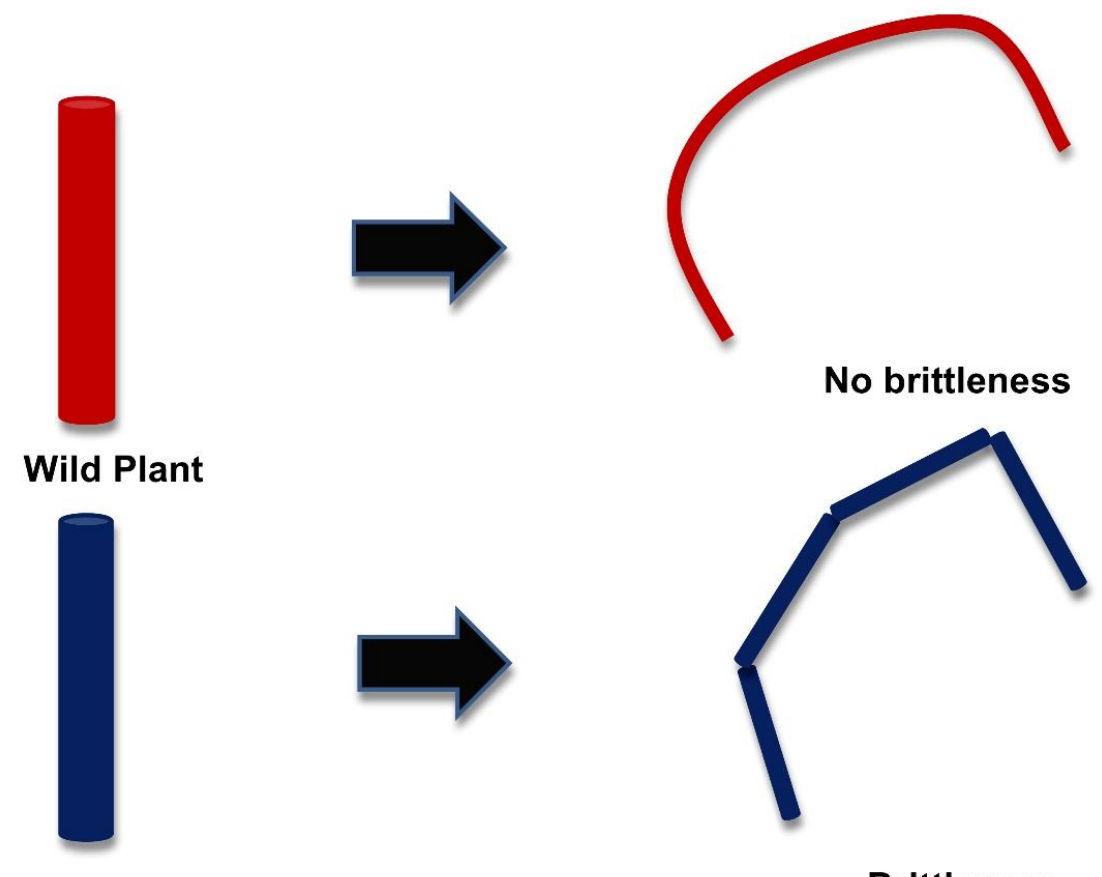

Mutant Plant

Brittleness

Figure 6. Wild and mutant plants showing similar agronomy traits, but brittleness was observed in the mutant plant after genetic modification.

\subsection{Wall Polymer Biosynthesis}

Cellulose synthase complexes (CESA) are known to be protein complexes involved in the synthesis of cellulose in higher plants [18]. These complexes, which are localized in the Golgi apparatus, synthesize cellulose in three steps after being transported to the plasma membrane. The three steps include the initiation of the $\beta$-1,4-glucan chain, followed by an elongation step, and completion of the process with the termination of the polymer chain [19]. The CESA complex is formed by the CeSA gene family, which have been characterized in multiple plant species including Arabidopsis, rice, cotton, barley, and poplar [20]. Some CeSA mutants have been explored by undertaking various genetic approaches to elaborate the biological functions of CeSA. However, maximum mutants resulted in reduced cellulose biosynthesis, accompanied by low crystallinity of the cell wall and abnormal plant growth. Overexpression of CesA genes led to a decreased biomass yield in transgenic plants of poplar and barley [21]. Only the Osbc13 mutant in rice, which has a substituted amino acid in OsCesA9, showed normal plant growth despite reduced cellulose [22].

Another gene family responsible for the expression of glycosyltransferases (GTs) is known as the GT family, which governs the synthesis of hemicellulose along with cellulose synthase like (Csl) genes [17]. Cellulose synthase like (Csl) genes encode glycan synthases located in the Golgi apparatus. The GT family is comprised of seven genes associated with the biosynthesis of hemicellulose. Several genetic mutants associated with hemicellulose synthesis have showcased a decreased biomass yield, along with improved digestibility and enzymatic saccharification [23]. For instance, mutants of GT43 and GT47 degrade xylan backbones.

Lignin biosynthesis calls for the involvement of multiple enzymes to synthesize the three monomer units of lignin. These enzymes include phenylalanine ammonia lyase, 4-coumarate-CoA ligase, cinnamate 4-hydroxylase, shikimate hydroxycinnamoyl transferase, caffeoyl-CoA 3-O-methyltransferase (CCoAOMT), coumarate 3hydroxylase, cinnamoyl-CoA reductase (CCR), ferulate 5-hydroxylase, cinnamyl alcohol dehydrogenase, and caffeic acid/5-hydroxyferulic acid O-methyltransferase (COMT). Many genetic mutants associated with the biosynthesis of lignin have been explored in a variety of plant species. SbCOMTs, comprising four site mutations in COMT, show lower lignin synthesis, along with 
an enhanced biomass digestibility in sorghum [24]. Similarly, Pv4CL1 gene silencing in switch grass plants also shows enhanced biomass digestibility by reducing the lignin content in the cell wall [25]. However, the down regulation of the genes also affected the growth and stress tolerance of the plants, which demotes the adoption of the lignin reduction approach for modifications in energy crops.

Researchers have also investigated the effect of genes associated with pectin biosynthesis. Expression of the fungal polygalacturonase and pectin methylesterase inhibitor resulted in improved enzymatic saccharification in Arabidopsis [26]. Similarly, suppressing the expression of pectin methylesterase (PME) resulted in a significant improvement in the biomass yield and enzymatic saccharification [2]. Similar outcomes were obtained in the case of QUA2, GAUT12, and PME3, however, enhanced digestibility was accompanied by adverse effects on plant growth in transgenic plants of Arabidopsis and poplar [27]. On the other hand, over expression of EXT and EXP genes not only enhanced biomass yield, but also improved its stress tolerance [28]. However, the effect of these genes on enzymatic digestibility is yet to be explored.

\subsection{Wall Polymer Degradation}

The sequential process followed by plants for remodeling of their cell wall relies on the adequate expression of various enzymes. The process usually starts with the expansion and separation of cells in which pectins are targeted. Hydrolysis of cell wall components via programmed cell death is activated from surrounding cells by downstream signaling [29]. This is followed by degradation of hemicellulose and cellulose. These common steps, required for cell wall degradation, are carried out by several enzymes and can be perceived as an integrated perspective. According to the modularity theory proposed by Grandis et al. [30], plants can be induced to alter the arrangement of their cell wall structure by overexpressing the key players from this step by step process.

Several enzymes are associated with cell wall degradation, such as endo- $\beta-1,4$-glucanases (EG), which cleaves the $\beta$-1,4-glycosidic links between glucose monomers. EG enzymes are part of the glycoside hydrolase 9 (GH9) family, which includes three subclasses according to enzyme specificity. Some of the mutants of this family, such as KORRIGON, PtCel9A1, OsGH9B etc., have been investigated for their effect on biomass yield and digestibility. KORRIGON mutants led to a reduced level of cellulose accompanied with abnormal plant growth, while PtCel9A1 mutants exhibited an increased biomass yield, with a reduction in cellulose content [6]. Similarly, the AtGH9C2 gene silencing was also reported to reduce the crystallinity of cellulose, as well as enhancing the biomass yield [6]. The OsGH9B mutant gene in rice also exhibited a significant correlation of gene expression with cellulose activity and the crystallinity index.

Apart from the GH9 enzyme, GH10 and GH11 enzymes were also reported to govern the degradation of hemicelluloses. In transgenic maize, overexpression of the GH11 gene resulted in improved biomass digestibility. On the other hand, RNAi silencing of the GH10 gene improved biomass yield in poplar [31].

Overexpression of PG and PL genes, associated with the degradation of pectin, enhanced the digestibility of biomass [32]. However, this overexpression resulted in a negative impact on biomass yield.

\subsection{Cell Wall Network Construction}

Network construction in the cell wall involves the crosslinking and deposition of polymers. Several transcription factors, such as NAC, SND, MYB, VND, and SWN, are involved in regulating the synthesis of the wall polymer network [33]. Overexpressing or silencing of genes encoding these factors can significantly affect the plant growth and biomass yield. As investigated by Petersen et al. [34], overexpression of the IRX gene, driven by the AtVND7 promoter, led to defective hemicellulose synthesis and resulted in an improved biomass yield and enzymatic digestibility. Overexpression of OsSWN1 improved biomass saccharification in rice [35]. Moreover, the site-specific mutations in the MYB factor altered the cell wall composition, thereby, improving the biomass digestibility 
without compromising plant growth. The study concluded that the strategies of site-specific mutations and adequate promoters can be adopted for genetic modifications of the cell wall, regulating transcriptional factors.

Construction of the cell wall network can also be altered by modifying the presence of chemical entities responsible for the interlinkage of constituents. For example, the three-monomer unit of lignin are interlinked by ester, ether, and covalent bonds. Reduction in these linkages can affect the quantity of lignin content and the mechanical strength of plants. Ralph et al. [36] decreased the $\beta$ aryl ether level by inducing site specific mutation in the $\mathrm{C} 3 \mathrm{H}$ gene and observed significant changes in plant growth in alfalfa mutants. Wilkerson et al. [37] replaced the ether bonds with esters and ferulic conjugates by overexpression of the AsFMT gene and revealed enhanced saccharification with no negative impact on plant growth.

Furthermore, incorporation of soluble polysaccharides in the cell wall can significantly improve biomass digestibility without any adverse impact on plant cell growth. For example, the addition of hyaluronan synthase in tobacco resulted in improved hydrolysis of cellulose [38]. Expression of the MLG synthase gene of rice in Arabidopsis incorporated $\beta-1,3-1,4$-glucans in the cell wall and resulted in a $42 \%$ increase of biomass saccharification [39].

\section{Approaches for Genetic Manipulations}

The genetic manipulation approach is based on target genes and the associated promoters in regulatory pathways (Table 2). Harris et al. [40] induced point mutation in the transmembrane domain region (C terminal) $\mathrm{CESA}^{\mathrm{A} 903 \mathrm{~V}}$ and CESA3 ${ }^{\mathrm{T} 942 \mathrm{I}}$ in Arabidopsis thaliana. Sahoo et al. [41] obtained a transgenic tobacco plant by overexpressing the CESA3 gene from Arabidopsis thaliana $\mathrm{L}$. They placed a CESA3 (ixr1-2) gene construct between the promoter M24 (proM24) and the rbcSE9 gene terminator. Handakumbura et al. [42] created loss-of-function mutants of BdCESA4 and BdCESA7 using microRNA constructs driven by a maize ubiquitin promoter (pUBI). Tan et al. [21] transformed barley plant by manipulating c DNA of HvCesA genes for the primary and secondary cell wall, driven by the CaMV 35S promoter. OsMYB103L, encoding the R2R3-MYB transcription factor in rice, was overexpressed, which further enhanced the expression of CESA genes to enhance cellulose content. On the other hand, knockdown of the gene OsMYB103L resulted in a lower expression of CESA genes, with cellulose content reduced by $13 \%$ [43] (Table 3).

Huang et al. [44] mutated gibberellin (GA) related genes for altering the expression of CESA genes and, consequently, the cellulose level. The down-regulation of CESA genes was observed in gibberellin deficient mutants. Chiniquy et al. [45] developed rice xax1 mutant plants, which were deficient in the aromatic compounds of ferulic acid and coumaric acid, thereby, reducing the presence of diferulic cross links. The mutant plants, therefore, exhibit enhanced saccharification. Chen et al. [7] developed a mutant rice plant in which dissociation transposon was inserted at the OsIRX10 locus to knock out the OsIRX10 gene that helps in the xylan backbone. The mutant rice revealed a $25 \%$ and $87 \%$ reduction in the thickness of the primary and secondary cell wall, respectively. A $10 \%$ reduction in xylose content was also observed due to a loss of the OsIRX10 gene function. Pawar et al. [46] revealed the regulation of the expression of the AnAXE1 gene by the 35S CAMV promoter and GT43B aspen promoter. The transgenic line revealed no significant change in wall composition. However, the xylan content, present in the cell wall, was observed to be more readily digestible by endogluconase. 
Table 2. Wall polymers and genetic approaches for their modifications.

\begin{tabular}{|c|c|c|c|c|c|c|c|c|c|}
\hline \multirow[b]{2}{*}{ S. No. } & \multirow[b]{2}{*}{ Species } & \multirow[b]{2}{*}{ Target Genes } & \multirow[b]{2}{*}{ Wall Polymer and Its Regulation } & \multicolumn{3}{|c|}{ Phenotypic Modifications } & \multirow[b]{2}{*}{ Pretreatment } & \multirow[b]{2}{*}{ Target for Pretreatment } & \multirow[b]{2}{*}{ Reference } \\
\hline & & & & $\begin{array}{l}\text { Cell Wall Structure and } \\
\text { Composition }\end{array}$ & $\begin{array}{l}\text { Biomass } \\
\text { Yield }\end{array}$ & $\begin{array}{c}\text { Enzymatic } \\
\text { Digestibility }\end{array}$ & & & \\
\hline 1 & Arabidopsis & AtCesA1, 3 & Cellulose synthesis & $\begin{array}{l}\text { Decrease in cellulose and } \\
\text { crystallinity index }\end{array}$ & I & + & ND & NA & {$[40]$} \\
\hline 2 & Tobacco & AtCESA3 & Cellulose synthesis & $\begin{array}{l}\text { No significant effect on cell } \\
\text { wall composition }\end{array}$ & - & + & ND & NA & [41] \\
\hline 3 & B. distachyon & BdCesA4, 7 & Cellulose synthesis & $\begin{array}{l}\text { Decrease in cellulose and } \\
\text { crystallinity index }\end{array}$ & - & / & ND & NA & [42] \\
\hline 4 & Barley & HvCesA4, 8 & Cellulose synthesis & $\begin{array}{l}\text { Decrease in cellulose and } \\
\text { crystallinity index }\end{array}$ & - & NA & ND & NA & [21] \\
\hline 5 & Arabidopsis & PttCel9A1 & Cellulose degradation & $\begin{array}{l}\text { Decrease in cellulose and } \\
\text { crystallinity index }\end{array}$ & + & NA & ND & NA & {$[47]$} \\
\hline 6 & Arabidopsis & PtGH9B5, C2 & Cellulose degradation & Increase in cellulose & - & NA & ND & NA & {$[6]$} \\
\hline 7 & Arabidopsis & AtGH9C2 & Cellulose degradation & $\begin{array}{l}\text { Decrease in cellulose and } \\
\text { crystallinity index }\end{array}$ & + & NA & ND & NA & [6] \\
\hline 8 & Rice & OsMYB103L & Cellulose regulation & $\begin{array}{l}\text { Increased secondary wall } \\
\text { thickness }\end{array}$ & / & NA & ND & NA & {$[43]$} \\
\hline 9 & Rice & $\begin{array}{l}\text { OsMYB61; } \\
\text { NAC29, } 31\end{array}$ & Cellulose regulation & $\begin{array}{c}\text { Increased secondary wall } \\
\text { thickness }\end{array}$ & / & NA & ND & NA & {$[44]$} \\
\hline 10 & Rice & OsXAX1 (GT61) & Hemicellulose synthesis & $\begin{array}{l}\text { Decrease in Xyl, ferulic, } \\
\text { coumaric acid }\end{array}$ & - & + & ND & NA & [45] \\
\hline 11 & Rice & OsIRX10 (GT47) & Hemicellulose synthesis & $\begin{array}{l}\text { Reduced ratio of xylose and } \\
\text { arabinose, affect growth }\end{array}$ & - & + & Hot water & Lignin & [7] \\
\hline 12 & Arabidopsis & AtTBL129 & Hemicellulose synthesis & Decrease in acetate content & NA & - & ND & NA & [48] \\
\hline 13 & Arabidopsis & AtESK1(DUF231) & Hemicellulose synthesis & Decrease in acetylated xylan & - & + & ND & NA & {$[8]$} \\
\hline 14 & Arabidopsis & AnAXE1 & Hemicellulose synthesis & Decrease in xylan content & / & + & $\begin{array}{l}\text { Hot water and } \\
\text { alkali }\end{array}$ & Lignin & {$[46]$} \\
\hline 15 & Arabidopsis & $\begin{array}{c}\text { AtMUR3/ } \\
\text { AtMURUS3 (GT47) }\end{array}$ & Hemicellulose synthesis & Decrease in xyloglucan & - & NA & ND & NA & [49] \\
\hline 16 & Arabidopsis & AtAXY9 (TBL) & Hemicellulose synthesis & Decrease in xyloglucan & - & NA & ND & NA & [50] \\
\hline
\end{tabular}


Table 2. Cont

\begin{tabular}{|c|c|c|c|c|c|c|c|c|c|}
\hline \multirow[b]{2}{*}{ S. No. } & \multirow[b]{2}{*}{ Species } & \multirow[b]{2}{*}{ Target Genes } & \multirow[b]{2}{*}{ Wall Polymer and Its Regulation } & \multicolumn{3}{|c|}{ Phenotypic Modifications } & \multirow[b]{2}{*}{ Pretreatment } & \multirow[b]{2}{*}{ Target for Pretreatment } & \multirow[b]{2}{*}{ References } \\
\hline & & & & $\begin{array}{l}\text { Cell Wall Structure and } \\
\text { Composition }\end{array}$ & $\begin{array}{l}\text { Biomass } \\
\text { Yield }\end{array}$ & $\begin{array}{c}\text { Enzymatic } \\
\text { Digestibility }\end{array}$ & & & \\
\hline 17 & Poplar & $\begin{array}{l}\text { PtGAUT12.1,12.2 } \\
\text { (GT8) }\end{array}$ & Hemicellulose synthesis & Reduce xylan content & + & + & $\begin{array}{c}\text { Thermal } \\
\text { pretreatment at } \\
180^{\circ} \mathrm{C} \\
\end{array}$ & Lignin & [23] \\
\hline 18 & Poplar & AtKNAT7 & Hemicellulose degradation & $\begin{array}{c}\text { Increased expression of IRX8, } \\
\text { IRX9, FRA8 }\end{array}$ & - & NA & ND & NA & [51] \\
\hline 19 & Alfalfa & MsHCT & Lignin synthesis & $\begin{array}{l}\text { Decreased lignin content; } \\
\text { increased H }\end{array}$ & - & NA & ND & NA & [52] \\
\hline 20 & Arabidopsis & AtCSE-1 & Lignin synthesis & $\begin{array}{l}\text { Decreased lignin content and } \\
\text { G monomer, increased H }\end{array}$ & - & + & ND & NA & [53] \\
\hline 21 & B. distachyon & BdCAD1 & Lignin synthesis & $\begin{array}{l}\text { Decrease in lignin content and } \\
\mathrm{S} \text { unit, increase in } \mathrm{H} \text { and } \mathrm{G} \\
\text { unit }\end{array}$ & / & + & ND & NA & [54] \\
\hline 22 & Poplar & PtCCR & Lignin synthesis & $\begin{array}{l}\text { Decrease in lignin content, } \\
\text { increase in G unit and } \\
\text { hemicellulose }\end{array}$ & - & + & $\begin{array}{l}\text { Alkaline and } \\
\text { acid }\end{array}$ & Lignin & [55] \\
\hline 23 & Sugarcane & $\mathrm{SbCOMT}$ & Lignin synthesis & Decreased lignin content & - & + & Acid & Lignin & [56] \\
\hline 24 & Switch grass & SbCOMT & Lignin synthesis & $\begin{array}{l}\text { Decreased lignin content, } \mathrm{S} \\
\text { and G ratio, increased } \\
\text { hemicellulose }\end{array}$ & / & + & ND & NA & [57] \\
\hline 25 & Poplar & AsFMT & Lignin interlinking & $\begin{array}{c}\text { Increased ferulic acid } \\
\text { conjugates, ester bonds and } \\
\text { Degradation of } \beta \text {-ether bonds }\end{array}$ & / & + & Alkaline & Lignin & [37] \\
\hline 26 & Arabidopsis & AtREF4 / AtRFR1 & Lignin regulation & $\begin{array}{l}\text { Increase in } \mathrm{G} \text { unit, reduction } \\
\text { of } S \text { unit and } S / G \text { ratio }\end{array}$ & NA & - & Hot water & Lignin & [58] \\
\hline 27 & Arabidopsis & AtQUA2-1 & Pectin synthesis & $\begin{array}{l}\text { Decrease of GalA and } \\
\text { de-methyl-esterified HG, } \\
\text { increase Gal and Xyl }\end{array}$ & - & + & ND & NA & [59] \\
\hline 28 & Poplar & PtGAUT12 & Pectin synthesis & $\begin{array}{l}\text { Decreased Xyl, GalA, HG, RG; } \\
\text { increased Man and Gal }\end{array}$ & + & + & $\begin{array}{c}\text { Thermal } \\
\text { pretreatment at } \\
180^{\circ} \mathrm{C}\end{array}$ & Lignin & [23] \\
\hline 29 & Arabidopsis & PcPL1 & Pectin degradation & Increase Glc; affect growth & - & + & ND & NA & [32] \\
\hline
\end{tabular}

+: Positive impact; -: negative impact; /: no significant impact; ND: not done; NA: not applicable. 
Table 3. Quantitative outcomes obtained after genetic modifications.

\begin{tabular}{|c|c|c|c|c|}
\hline S. No. & Plant & Modified Gene & Outcomes & Reference \\
\hline 1 & Arabidopsis & AtCesA1, 3 & $8 \%$ decrease in crystallanity & [40] \\
\hline 2 & Tobacco & AtCESA3 & $54 \%-66 \%$ increase in enzymatic saccharification & [41] \\
\hline 3 & Arabidopsis & PtGH9B5 & slight decreases in each carbohydrate & [6] \\
\hline 4 & Rice & OsMYB103L & $13 \%$ decrease in cellulose content, & [43] \\
\hline 5 & Rice & OsIRX10 (GT47) & $\begin{array}{l}10 \% \text { reduction in xylose, } 25 \text { and } 87 \% \text { reduction in } \\
\text { thickness of primary and secondary cell wall }\end{array}$ & [7] \\
\hline 6 & Arabidopsis & AtESK1 (DUF231) & $\begin{array}{l}\text { smaller rosette leaves and shorter inflorescence stems, } \\
35 \% \text { reduction in secondary wall thickness }\end{array}$ & [8] \\
\hline 7 & Arabidopsis & AtAXY9 (TBL) & $35 \%$ decrease in xylan, $18 \%$ decrease in pectin fraction & [50] \\
\hline 8 & Sugarcane & SbCOMT & $\begin{array}{l}29 \% \text { increase in glucose yield without pretreatment } \\
\text { and 34\% after pretreatment }\end{array}$ & [56] \\
\hline 9 & Switch grass & $\mathrm{SbCOMT}$ & $\begin{array}{l}34 \% \text { increase in sugar yield and } 285 \text { increase in } \\
\text { ethanol yield from transgenic line }\end{array}$ & [57] \\
\hline 10 & Poplar & AsFMT & $\begin{array}{l}\text { Almost } 2 \text { fold increase in saccharification yield after } \\
\text { pretreatment as compared to wild type }\end{array}$ & [37] \\
\hline 11 & Arabidopsis & AtREF4/ AtRFR1 & $30 \%$ increase in glucose yield, & [58] \\
\hline 12 & Arabidopsis & AtQUA2-1 & $\begin{array}{l}43 \% \text { increase in saccharification yield after enzymatic } \\
\text { hydrolysis }\end{array}$ & [59] \\
\hline
\end{tabular}

\section{Conclusions and Future Aspects}

To maximize biomass yield and digestibility and obtain the desired valuable products there is a need to overcome the recalcitrance pertaining to the complex cell wall structure. In this regard, the manipulation of gene encoding of the proteins responsible for the regulation of the cell wall structure and composition seems to be an appropriate strategy. This strategy also holds significance since it not only brings about the desired changes in the current generation of transgenic plants, but also helps to stabilize those desired features in the generations which will evolve from these plants. The structural modifications resulted from altering the gene pool increase the digestibility of plants by altering the composition of cell wall constituents and the distribution of crystalline and amorphous regions. The challenge that persists in the adoption of genetic modification strategies is the adverse effects on the tolerance and growth of plants due to a reduction of constituents providing protection and mechanical strength to the plant. Therefore, intensive studies are required to identify the gene targets, along with the appropriate genetic modification approach to enhance the digestibility without compromising the natural protective mechanisms of plants, which are crucial for their survival and optimum growth.

Author Contributions: M.Y. and K.P. has contributed equally to this review paper. A.C., N.P. and V.V. contributed with the proofreading, comments and improving the quality of manuscript.

Acknowledgments: M.Y. and K.P. would like to acknowledge Centre for Energy and Envronment, Malaviya National Institute of Technology, Jaipur for facilities and fellowship provided. V.V. would like to thank Department of Biotechnology and Department of Science and Technology, Government of India for financial support.

Conflicts of Interest: The authors report no conflicts of interest. The authors alone are responsible for the content and writing of the paper.

\section{References}

1. Himmel, M.E.; Bayer, E.A. Lignocellulose conversion to biofuels: Current challenges, global perspectives. Curr. Opin. Biotechnol. 2009, 20, 316-317. [CrossRef] [PubMed]

2. Chen, P.; Peng, L.C. The diversity of lignocellulosic biomass resources and their evaluation for use as biofuels and chemicals. In Biological Conversion of Biomass for Fuels and Chemicals: Explorations from Natural Biomass Utilization Systems; Sun, J.Z., Ding, S.Y., Peterson, J.D., Eds.; Royal Society of Chemistry: Cambridge, UK, 2013; pp. 83-109. 
3. Wang, Y.T.; Xu, Z.D.; Peng, L.C. Model of plant cell wall ditches structure for enhancing biomass saccharification and plant resistances. Sci. Sin. Vitae 2014, 44, 766-774. [CrossRef]

4. Xie, G.S.; Peng, L.C. Genetic engineering of energy crops: A strategyfor biofuel production in China. J. Integr. Plant Biol. 2011, 53, 143-150. [CrossRef] [PubMed]

5. Li, F.C.; Zhang, M.L.; Guo, K.; Hu, Z.; Zhang, R.; Feng, Y.Q.; Yi, X.; Zou, W.; Wang, L.; Wu, C.; et al. High-level hemicellulosic arabinose predominately affects lignocellulose crystallinity for genetically enhancing both plant lodging resistance and biomass enzymatic digestibility in rice mutants. Plant Biotechnol. J. 2015, 13, 514-525. [CrossRef] [PubMed]

6. Glass, M.; Barkwill, S.; Unda, F.; Mansfield, S.D. Endo-beta-1,4-glucanases impact plant cell wall development by influencing cellulose crystallization. J. Integr. Plant Biol. 2015, 57, 396-410. [CrossRef] [PubMed]

7. Chen, X.W.; Vega-Sánchez, M.; Verhertbruggen, Y.; Chiniquy, D.; Canlas, P.E.; Fagerström, A.; Prak, L.; Christensen, U.; Oikawa, A.; Chern, M.; et al. Inactivation of OsIRX10 leads to decreased xylan content in rice culm cell walls and improved biomass saccharification. Mol. Plant 2013, 6, 570-573. [CrossRef] [PubMed]

8. Yuan, Y.X.; Teng, Q.; Zhong, R.Q.; Ye, Z.H. The Arabidopsis DUF231 domain-containing protein ESK1 mediates 2-O- and 3-O-acetylation of xylosyl residues in xylan. Plant Cell Physiol. 2013, 54, 1186-1199. [CrossRef] [PubMed]

9. Brown, S.P.; Emsley, L. The 2D MAS NMR spin-echo experiment: The determination of ${ }^{13} \mathrm{C}-{ }^{13} \mathrm{C} J$ couplings in a solid-state cellulose sample. J. Magn. Reson. 2004, 171, 43-47. [CrossRef] [PubMed]

10. Kaida, R.; Kaku, T.; Baba, K.; Oyadomari, M.; Watanabe, T.; Nishida, K.; Kanaya, T.; Shani, Z.; Shoseyov, O.; Hayashi, T. Loosening xyloglucan accelerates the enzymatic degradation of cellulose in wood. Mol. Plant 2009, 2, 904-909. [CrossRef] [PubMed]

11. Girio, F.M.; Fonseca, C.; Carvalheiro, F.; Duarte, L.C.; Marques, S.; Bogel-Łukasik, R. Hemicelluloses for fuel ethanol: A review. Bioresour. Technol. 2010, 101, 4775-4800. [CrossRef] [PubMed]

12. Kumar, S.; Paritosh, K.; Pareek, N.; Chawade, A.; Vivekanand, V. De-construction of major Indian cereal crop residues through chemical pretreatment for improved biogas production: An overview. Renew. Sustain. Energy Rev. 2018, 90, 160-170. [CrossRef]

13. Chawade, A.; Alexandersson, E.; Bengtsson, T.; Andreasson, E.; Levander, F. Targeted Proteomics Approach for Precision Plant Breeding. J. Proteome Res. 2016, 15, 638-646. [CrossRef] [PubMed]

14. Lindlof, A.; Brautigam, M.; Chawade, A.; Olsson, O.; Olsson, B. In silico analysis of promoter regions from cold-induced genes in rice (Oryza sativa L.) and Arabidopsis thaliana reveals the importance of combinatorial control. Bioinformatics 2009, 25, 1345-1348. [CrossRef] [PubMed]

15. Chawade, A.; Sikora, P.; Bräutigam, M.; Larsson, M.; Vivekanand, V.; Nakash, M.; Chen, T.; Olsson, O. Development and characterization of an oat TILLING-population and identification of mutations in lignin and $\beta$-glucan biosynthesis genes. BMC Plant Biol. 2010, 10, 86. [CrossRef] [PubMed]

16. Vivekanand, V.; Chawade, A.; Larsson, M.; Larsson, A.; Olsson, O. Identification and qualitative characterization of high and low lignin lines from an oat TILLING population. Ind. Crops Prod. 2014, 59, 1-8. [CrossRef]

17. Guo, K.; Zou, W.; Feng, Y.; Zhang, M.; Zhang, J.; Tu, F.; Xie, G.; Wang, L.; Wang, Y.; Klie, S.; et al. An integrated genomic and metabolomic frame work for cell wall biology in rice. BMC Genom. 2014, 15, 596. [CrossRef] [PubMed]

18. Brabham, C.; DeBolt, S. Chemical genetics to examine cellulose biosynthesis. Front. Plant Sci. $2013,3,309$. [CrossRef] [PubMed]

19. Peng, L.C.; Kawagoe, Y.S.; Hogan, P.; Delmer, D. Sitosterol-beta-glucoside as primer for cellulose synthesis in plants. Science 2002, 295, 147-150. [CrossRef] [PubMed]

20. Li, A.; Xia, T.; Xu, W.; Chen, T.T.; Li, X.L.; Fan, J.; Wang, R.; Feng, S.; Wang, Y.; Wang, B.; et al. An integrative analysis of four CESA isoforms specific for fiber cellulose production between Gossypium hirsutum and Gossypium barbadense. Planta 2013, 237, 1585-1597. [CrossRef] [PubMed]

21. Tan, H.T.; Shirley, N.J.; Singh, R.R.; Henderson, M.; Dhugga, K.S.; Mayo, G.M.; Fincher, G.B.; Burton, R.A. Powerful regulatory systems and post-transcriptional gene silencing resist increases in cellulose content in cell walls of barley. BMC Plant Biol. 2015, 15, 62. [CrossRef] [PubMed]

22. Song, X.Q.; Liu, L.F.; Jiang, Y.J.; Zhang, B.C.; Gao, Y.P.; Liu, X.L.; Lin, Q.S.; Ling, H.Q.; Zhou, Y.H. Disruption of secondary wall cellulose biosynthesis alters cadmium translocation and tolerance in rice plants. Mol. Plant 2013, 6, 768-780. [CrossRef] [PubMed] 
23. Biswal, A.K.; Hao, Z.Y.; Pattathil, S.; Yang, X.H.; Winkeler, K.; Collins, C.; Mohanty, S.S.; Richardson, E.A.; Gelineo-Albersheim, I.; Hunt, K.; et al. Downregulation of GAUT12 in Populus deltoides by RNA silencing results in reduced recalcitrance, increased growth and reduced xylan and pectin in a woody biofuel feedstock. Biotechnol. Biofuels 2015, 8, 41. [CrossRef] [PubMed]

24. Sattler, S.E.; Palmer, N.A.; Saballos, A.; Greene, A.M.; Xin, Z.G.; Sarath, G.; Vermerris, W.; Pedersen, J.F. Identification and characterization of four missense mutations in Brown midrib 12 (Bmr12), the caffeic O-methyltranferase (COMT) of sorghum. Bioenergy Res. 2012, 5, 855-865. [CrossRef]

25. Xu, B.; Escamilla-Treviño, L.L.; Sathitsuksanoh, N.; Shen, Z.; Shen, H.; Zhang, Y.H.; Dixon, R.A.; Zhao, B. Silencing of 4-coumarate: Coenzyme A ligase in switchgrass leads to reduced lignin content and improved fermentable sugar yields for biofuel production. New Phytol. 2011, 192, 611-625. [CrossRef] [PubMed]

26. Lionetti, V.; Francocci, F.; Ferrari, S.; Volpi, C.; Bellincampi, D.; Galletti, R.; D'Ovidio, R.; De Lorenzo, G.; Cervone, F. Engineering the cell wall by reducing de-methyl-esterified homogalacturonan improves saccharification of plant tissues for bioconversion. Proc. Natl. Acad. Sci. USA 2010, 107, 616-621. [CrossRef] [PubMed]

27. Biswal, A.K.; Soeno, K.; Gandla, M.L.; Immerzeel, P.; Pattathil, S.; Lucenius, J.; Serimaa, R.; Hahn, M.G.; Moritz, T.; Jönsson, L.J.; et al. Aspen pectate lyase PtxtPL1-27 mobilizes matrix polysaccharides from woody tissues and improves saccharification yield. Biotechnol. Biofuels 2014, 7, 11. [CrossRef] [PubMed]

28. Choudhary, P.; Saha, P.; RayT, T.Y.H.; Yang, D.; Cannon, M.C. EXTENSIN18 is required for full male fertility as well as normal vegetative growth in Arabidopsis. Front. Plant Sci. 2015, 6, 553. [PubMed]

29. Tavares, E.Q.P.; De Souza, A.P.; Buckeridge, M.S. How endogenous plant cell-wall degradation mechanisms can help achieve higher efficiency in saccharification of biomass. J. Exp. Bot. 2015, 66, 4133-4143. [CrossRef] [PubMed]

30. De Souza, A.P.; Grandis, A.; Leite, D.C.C.; Buckeridge, M.S. Sugarcane as a bioenergy source: History, performance, and perspectives for second-generation bioethanol. BioEnergy Res. 2014, 7, 24-35. [CrossRef]

31. Derba-Maceluch, M.; Awano, T.; Takahashi, J.; Lucenius, J.; Ratke, C.; Kontro, I.; Busse-Wicher, M.; Kosik, O.; Tanaka, R.; Winzéll, A.; et al. Suppression of xylan endotransglycosylase PtxtXyn10A affects cellulose microfibril angle in secondary wall in aspen wood. New Phytol. 2014, 205, 666-681. [CrossRef] [PubMed]

32. Tomassetti, S.; Pontiggia, D.; Verrascina, I.; Reca, I.B.; Francocci, F.; Salvi, G.; Cervone, F.; Ferrari, S. Controlled expression of pectic enzymes in Arabidopsis thaliana enhances biomass conversion without adverse effects on growth. Phytochemistry 2015, 112, 221-230. [CrossRef] [PubMed]

33. Zhong, R.Q.; Ye, Z.H. Regulation of cell wall biosynthesis. Curr. Opin. Plant Biol. 2007, 10, $564-572$. [CrossRef] [PubMed]

34. Petersen, P.D.; Lau, J.; Ebert, B.; Yang, F.; Verhertbruggen, Y.; Kim, J.S.; Varanasi, P.; Suttangkakul, A.; Auer, M.; Loqué, D.; et al. Engineering of plants with improved properties as biofuels feedstocks by vesselspecific complementation of xylan biosynthesis mutants. Biotechnol. Biofuels 2012, 5, 84. [CrossRef] [PubMed]

35. Yoshida, K.; Sakamoto, S.; Kawai, T.; Kobayashi, Y.; Sato, K.; Ichinose, Y.; Yaoi, K.; Akiyoshi-Endo, M.; Sato, H.; Takamizo, T.; et al. Engineering the Oryza sativa cell wall with rice NAC transcription factors regulating secondary wall formation. Front. Plant Sci. 2013, 4, 383. [CrossRef] [PubMed]

36. Ralph, J.; Akiyama, T.; Kim, H.; Lu, F.; Schatz, P.F.; Marita, J.M.; Ralph, S.A.; Reddy, M.S.; Chen, F.; Dixon, R.A. Effects of coumarate 3-hydroxylase down-regulation on lignin structure. J. Biol. Chem. 2006, 281, 8843-8853. [CrossRef] [PubMed]

37. Wilkerson, C.G.; Mansfield, S.D.; Lu, F.; Withers, S.; Park, J.Y.; Karlen, S.D.; Gonzales-Vigil, E.; Padmakshan, D.; Unda, F.; Rencoret, J.; et al. Monolignol ferulate transferase introduces chemically labile linkages into the lignin backbone. Science 2014, 344, 90-93. [CrossRef] [PubMed]

38. Abramson, M.; Shoseyov, O.; Shani, Z. Plant cell wall reconstruction toward improved lignocellulosic production and processability. Plant Sci. 2010, 178, 61-72. [CrossRef]

39. Vega-Sánchez, M.E.; Loqué, D.; Lao, J.; Catena, M.; Verhertbruggen, Y.; Herter, T.; Yang, F.; Harholt, J.; Ebert, B.; Baidoo, E.E.; et al. Engineering temporal accumulation of a low recalcitrance polysaccharide leads to increased C6 sugar content in plant cell walls. Plant Biotechnol. J. 2015, 13, 903-914. [CrossRef] [PubMed]

40. Harris, D.M.; Corbin, K.; Wang, T.; Gutierrez, R.; Bertolo, A.L.; Petti, C.; Smilgies, D.M.; Estevez, J.M.; Bonetta, D.; Urbanowicz, B.R.; et al. Cellulose microfibril crystallinity is reduced by mutating C-terminal transmembrane region residues CESA1A903V and CESA3T942I of cellulose synthase. Proc. Natl. Acad. Sci. USA 2012, 109, 4098-4103. [CrossRef] [PubMed] 
41. Sahoo, D.K.; Stork, J.; DeBolt, S.; Maiti, I.B. Manipulating cellulose biosynthesis by expression of mutant Arabidopsis proM24: CESA3 $3^{i x r 1-2}$ gene in transgenic tobacco. Plant Biotechnol. J. 2013, 11, 362-372. [CrossRef] [PubMed]

42. Handakumbura, P.P.; Matos, D.A.; Osmont, K.S.; Harrington, M.J.; Heo, K.; Kafle, K.; Kim, S.H.; Baskin, T.I.; Hazen, S.P. Perturbation of Brachypodium distachyon CELLULOSE SYNTHASE A4 or 7 results in abnormal cell walls. BMC Plant Biol. 2013, 13, 131. [CrossRef] [PubMed]

43. Yang, C.H.; Li, D.Y.; Liu, X.; Ji, C.J.; Hao, L.L.; Zhao, X.F.; Li, X.B.; Chen, C.Y.; Cheng, Z.K.; Zhu, L.H. OsMYB103L, an R2R3MYB transcription factor, influences leaf rolling and mechanical strength in rice (Oryza sativa L.). BMC Plant Biol. 2014, 14, 158. [CrossRef] [PubMed]

44. Huang, D.; Wang, S.; Zhang, B.; Shang-Guan, K.; Shi, Y.; Zhang, D.; Liu, X.; Wu, K.; Xu, Z.; Fu, X.; et al. A gibberellin-mediated DELLA-NAC signaling cascade regulates cellulose synthesis in rice. Plant Cell 2015, 27, 1681-1696. [CrossRef] [PubMed]

45. Chiniquy, D.; Sharma, V.; Schultink, A.; Baidoo, E.E.; Rautengarten, C.; Cheng, K.; Carroll, A.; Ulvskov, P.; Harholt, J.; Keasling, J.D.; et al. XAX1 from glycosyltransferase family 61 mediates xylosyltransfer to rice xylan. Proc. Natl. Acad. Sci. USA 2012, 109, 17117-17122. [CrossRef] [PubMed]

46. Pawar, P.M.A.; Derba-Maceluch, M.; Chong, S.L.; Gómez, L.D.; Miedes, E.; Banasiak, A.; Ratke, C.; Gaertner, C.; Mouille, G.; McQueen-Mason, S.J.; et al. Expression of fungal acetyl xylan esterase in Arabidopsis thaliana improves saccharification of stem lignocellulose. Plant Biotechnol. J. 2015, 14, 387-397. [CrossRef] [PubMed]

47. Takahashi, J.; Rudsander, U.J.; Hedenstrom, M.; Banasiak, A.; Harholt, J.; Amelot, N.; Immerzeel, P.; Ryden, P.; Endo, S.; Ibatullin, F.M.; et al. KORRIGAN1 and its aspen homolog PttCel9A1 decrease cellulose crystallinity in Arabidopsis stems. Plant Cell Physiol. 2009, 50, 1099-1115. [CrossRef] [PubMed]

48. Xiong, G.Y.; Cheng, K.; Pauly, M. Xylan O-acetylation impacts xylem development and enzymatic recalcitrance as indicated by the Arabidopsis mutant tbl29. Mol. Plant 2013, 6, 1373-1375. [CrossRef] [PubMed]

49. Kong, Y.Z.; Peña, M.J.; Renna, L.; Avci, U.; Pattathil, S.; Tuomivaara, S.T.; Li, X.; Reiter, W.D.; Brandizzi, F.; Hahn, M.G.; et al. Galactose-depleted xyloglucan is dysfunctional and leads to dwarfism in Arabidopsis. Plant Physiol. 2015, 167, 1296-1306. [CrossRef] [PubMed]

50. Schultink, A.; Naylor, D.; Dama, M.; Pauly, M. The role of the plant-specific ALTERED XYLOGLUCAN 9 protein in Arabidopsis cell wall polysaccharide O-acetylation. Plant Physiol. 2015, 167, 1271-1283. [CrossRef] [PubMed]

51. Li, E.; Bhargava, A.; Qiang, W.; Friedmann, M.C.; Forneris, N.; Savidge, R.A.; Johnson, L.A.; Mansfield, S.D.; Ellis, B.E.; Douglas, C.J. The Class II KNOX gene KNAT7 negatively regulates secondary wall formation in Arabidopsis and is functionally conserved in Populus. New Phytol. 2012, 194, 102-115. [CrossRef] [PubMed]

52. Gallego-Giraldo, L.; Bhattarai, K.; Pislariu, C.; Nakashima, J.; Jikumaru, Y.; Kamiya, Y.; Udvardi, M.K.; Monteros, M.J.; Dixon, R.A. Lignin modification leads to increased nodule numbers in alfalfa. Plant Physiol. 2014, 164, 1139-1150. [CrossRef] [PubMed]

53. Vanholme, R.; Cesarino, I.; Rataj, K.; Xiao, Y.; Sundin, L.; Goeminne, G.; Kim, H.; Cross, J.; Morreel, K.; Araujo, P.; et al. Caffeoyl Shikimate Esterase (CSE) is an enzyme in the lignin biosynthetic pathway in Arabidopsis. Science 2013, 341, 1103-1106. [CrossRef] [PubMed]

54. Bouvier d'Yvoire, M.; Bouchabke-Coussa, O.; Voorend, W.; Antelme, S.; Cézard, L.; Legée, F.; Lebris, P.; Legay, S.; Whitehead, C.; McQueen-Mason, S.J.; et al. Disrupting the cinnamyl alcohol dehydrogenase 1 gene (BdCAD1) leads to altered lignification and improved saccharification in Brachypodium distachyon. Plant J. 2013, 73, 496-508. [CrossRef] [PubMed]

55. Van Acker, R.; Lepléc, J.C.; Aerts, D.; Stormea, V.; Goeminne, G.; Ivens, B.; Légée, F.; Lapierre, C.; Piens, K.; Van Montagu, M.C.; et al. Improved saccharification and ethanol yield from field-grown transgenic poplar deficient in cinnamoyl-CoA reductase. Proc. Natl. Acad. Sci. USA 2014, 111, 845-850. [CrossRef] [PubMed]

56. Jung, J.H.; Fouad, W.M.; Vermerris, W.; Gallo, M.; Altpeter, F. RNAi suppression of lignin biosynthesis in sugarcane reduces recalcitrance for biofuel production from lignocellulosic biomass. Plant Biotechnol. J. 2012, 10, 1067-1076. [CrossRef] [PubMed]

57. Baxter, H.L.; Mazarei, M.; Labbe, N.; Kline, L.M.; Cheng, Q.; Windham, M.T.; Mann, D.G.; Fu, C.; Ziebell, A.; Sykes, R.W.; et al. Two-year field analysis of reduced recalcitrance transgenic switchgrass. Plant Biotechnol. J. 2014, 12, 914-924. [CrossRef] [PubMed] 
58. Bonawitz, N.D.; Kim, J.I.; Tobimatsu, Y.; Ciesielski, P.N.; Anderson, N.A.; Ximenes, E.; Maeda, J.; Ralph, J.; Donohoe, B.S.; Ladisch, M.; et al. Disruption of mediator rescues the stunted growth of a lignin-deficient Arabidopsis mutant. Nature 2014, 509, 376-380. [CrossRef] [PubMed]

59. Francocci, F.; Bastianelli, E.; Lionetti, V.; Ferrari, S.; De Lorenzo, G.; Bellincampi, D.; Cervone, F. Analysis of pectin mutants and natural accessions of Arabidopsis highlights the impact of de-methyl-esterified homogalacturonan on tissue saccharification. Biotechnol. Biofuel 2013, 6, 163. [CrossRef] [PubMed]

(C) 2018 by the authors. Licensee MDPI, Basel, Switzerland. This article is an open access article distributed under the terms and conditions of the Creative Commons Attribution (CC BY) license (http:/ / creativecommons.org/licenses/by/4.0/). 